\title{
Population-based study of breast cancer in older women: prognostic factors of relative survival and predictors of treatment
}

Pegdwende Olivia Dialla ${ }^{1,2}$, Tienhan Sandrine Dabakuyo ${ }^{1,2^{*}}$, Sophie Marilier ${ }^{3}$, Julie Gentil ${ }^{1,2}$, Patrick Roignot ${ }^{4}$, Ariane Darut-Jouve ${ }^{5}$, Marie-Laure Poillot ${ }^{1,2}$, Valérie Quipourt ${ }^{3}$ and Patrick Arveux ${ }^{1,2}$

\begin{abstract}
Background: A large proportion of women with breast cancer (BC) are elderly. However, there is a lack of information regarding $B C$ prognostic factors and care in this population. The aims of this study were to assess the prognostic factors of relative survival (RS) among women with BC aged $\geq 75$ years old and to identify the predictive factors of treatments administered to this population.

Methods: A population-based study was performed using data from the Cote d'Or breast and gynaecological cancer registry. Women aged 75 years and older with primary invasive BC and resident in Cote d'Or at the time of diagnosis made between January 1998 and December 2008 were retrospectively selected. Prognostic factors of RS were estimated in a generalized linear model with a Poisson error structure. RS rate for the whole population was given at 5 years. Logistic regression models were used to identify the predictors of the treatments administered.

Results: Six hundred and eighty-one women were included. Median age at diagnosis was 80 . Comorbidities $(p=0.02)$, $p$ T stage $(p=0.04)$, metastases $(p=<0.001)$, having a family doctor $(p=0.03)$ and hormone-receptor status $(p=0.006)$ were independent prognostic factors of RS. The RS rate at 5 years for the whole population was $78.2 \%$, $95 \% \mathrm{Cl}=[72.2-83.0]$. Age, pT stage, metastases, histoprognostic SBR grade, hormone receptor status and comorbidities were frequently found to be predictors of treatment with surgery alone, hormone therapy alone, breast conserving surgery plus adjuvant therapy and mastectomy plus adjuvant therapy.

Conclusions: Comorbid conditions adversely affect survival in older women with breast cancer. Moreover the results of this study showed that there are numerous predictors of the type of treatment administered, and that the most important were age and comorbidities.
\end{abstract}

Keywords: Breast cancer, Elderly women, Predictors of treatment, Prognostic factors, Relative survival

\section{Background}

Breast cancer $(\mathrm{BC})$ is the most common malignancy in women in France [1-4]. With the aging population and the increase in life expectancy, cancer in elderly people is increasing and this now constitutes a major public health concern.

\footnotetext{
* Correspondence: sdabakuyo@cgfl.fr

${ }^{1}$ Breast and Gynaecologic Cancer Registry of Cote d'Or, Centre Georges François Leclerc, 1 rue Professeur Marion BP 77980, Dijon Cedex 21079, France

${ }^{2}$ EA 4184, Faculty of Medicine, University of Burgundy, 7 boulevard Jeanne d'Arc, Dijon 21000, France

Full list of author information is available at the end of the article
}

Many studies have reported data about the prognostic factors of survival among women with BC [5,6]. Despite improved knowledge of these prognostic factors, there are no data about the prognostic factors of relative survival (RS) among older women with $\mathrm{BC}$ in a whole population.

The treatment strategy for $\mathrm{BC}$ is based on the initial stage of the tumour, the patient's age, general health, tumour histology and prognostic factors [7]. Progress made in the diagnosis and therapeutic management of $\mathrm{BC}$ [8-10] has led to improvements in prognosis and overall quality of survival [11]. However, elderly women with $\mathrm{BC}$ are currently undertreated in comparison with the youngest, and this leads to a considerable decrease

\section{Biomed Central}


in specific survival [12-14]. Current therapeutic approaches in older women are most often empiric. Therapeutic decisions are based on wishful thinking on behalf of patients and their loved ones and on the clinician's impressions [15-18]. Moreover, $12 \%$ of patients with $\mathrm{BC}$ aged $\geq 80$ years old do not receive treatment and $44 \%$ do not undergo surgery. Older women are also less likely to receive treatment in compliance with guidelines [19]. In addition, comorbidities, which are particularly common among older women, complicated the management of cancer treatment [20].

Contrary to a long-standing belief, $\mathrm{BC}$ can be as aggressive in elderly patients as in younger women. Consequently, the management of older patients with $\mathrm{BC}$ should not differ from that in young patients. However, the predictors of treatment in the elderly have not yet been clearly assessed $[13,14]$.

Cancer registries provide a unique opportunity to assess survival and to evaluate the predictors of treatments given in routine practice in this population on comprehensive population-based data.

The first aim of this study was to assess the prognostic factors of RS among women with $\mathrm{BC}$ aged $\geq 75$ years. The secondary purpose was to identify the predictors of treatment in this population.

\section{Methods}

\section{Population}

A population-based study was undertaken using data from the Cote d'Or breast and gynaecological cancer registry. This registry is the only one in France that focuses on breast and gynaecological cancers. It has been collecting comprehensive population-based data since 1982. Women aged 75 years and older with primary invasive BC and residing in Cote d'Or at the time of diagnosis made between January 1998 and December 2008 were retrospectively selected. Women lost at the date of diagnosis were excluded. For patients with synchronous bilateral BC, the most advanced tumour according to the number of positive nodes, the tumour size, the Scarff, Bloom, and Richardson (SBR) grade, and the tumour histology was included.

\section{Studied variables and end points}

All patients were staged according to the TNM system [21]. We considered the pathologic TNM (pTNM) classification or, when absent, the clinical TNM (cTNM) classification. We used the cTNM for the predictors of treatments because the categories of treatments included surgery or other exclusive treatments without surgery; the pTNM could therefore not be used, and for the prognostic factors we used the pTNM, replaced by the cTNM when the patients were not treated with surgery.

Age at diagnosis was categorized into three classes: 75-79 years, $80-84$ years and $\geq 85$ years. Pathological tumour size and the number of removed and positive nodes were also recorded. Removed nodes were categorized into two classes: $\leq 10$ nodes and $>10$ nodes and positive nodes into three classes: $0,1-3$ and $\geq 4$ nodes. Tumour characteristics, such as SBR grade classified as grades $1+2$ or grade 3 , and hormone receptor status, considered positive when oestrogen and/or progesterone were positive, were also collected. Clinical and demographic data, such as the circumstances of diagnosis (clinical diagnosis or individual screening), the matrimonial status (single or not), having a family doctor (yes or no), the vital status (dead or alive) and the place of residence (rural or urban) were recorded too. The comorbidities were collected at the diagnosis, as were all of the diseases associated with $\mathrm{BC}$ at the time of diagnosis: diabetes, high blood pressure, neurological disease (Alzheimer, Parkinson, epilepsy), psychiatric illness, tuberculosis, thyroid disorder, genetic abnormalities and previous history of disease affecting treatment administration. Comorbidities were classified in two categories: at least one comorbidity and no comorbidity. The period of diagnosis was split into two: 1998-2003 and 2004-2008 according to the median of distribution. Treatments were grouped into exclusive categories: surgery alone, hormone therapy alone, breastconserving surgery plus adjuvant therapy (BCS plus adjuvant therapy) and mastectomy plus adjuvant therapy. Patients without treatment constituted the "no treatment" category, and the "others" category was used for the following exclusive treatments: chemotherapy alone, radiotherapy alone, chemotherapy plus hormone therapy, chemotherapy plus radiotherapy, radiotherapy plus hormone therapy, chemotherapy plus radiotherapy plus hormone therapy, neoadjuvant chemotherapy plus surgery plus adjuvant therapy and neoadjuvant chemotherapy plus surgery.

Survival was calculated from the date of diagnosis until the date of death or the date of last follow-up. The cut-off date for the survival analysis was set at 01 January 2010. Patients who were alive after the cut-off date were censored.

\section{Statistical methods}

Quantitative variables are given as means, standard deviations (SD), medians and ranges, while qualitative variables are given as percentages. The percentage of missing values is also provided.

Treatments categories were compared according to the follow-up periods using Chi2 tests. CochranArmitage trend tests were used to compare treatments according to the age classes.

RS rate with the $95 \%$ confidence interval (CI) for the whole population was given at 5 years. RS is an estimator of the excess mortality ratio (EMR) estimated from life tables as the ratio of the observed survival of the patients (where all deaths are considered events) to the expected survival (ES) [22]. The ES was estimated using Cote d'Or female life-expectancy tables stratified by age 
Table 1 Characteristics of patients $(\mathrm{N}=681)$ and tumours

\begin{tabular}{|c|c|c|c|c|}
\hline Variables & $N(681)$ & $\%$ & Mean (SD) & $\begin{array}{c}\text { Median } \\
\text { [min;max] }\end{array}$ \\
\hline Age at diagnosis (years) & 681 & & $81.3(5.2)$ & $80.0[75 ; 98]$ \\
\hline Pathological tumor size $(\mathrm{mm})$ & 546 & & $27.0(19.8)$ & $22.0[2 ; 160]$ \\
\hline Nodes removed & 612 & & $8.2(6.3)$ & $8.0[0 ; 32]$ \\
\hline Positive nodes & 519 & & $2.0(4.0)$ & $0.0[0 ; 32]$ \\
\hline \multicolumn{5}{|l|}{ Age } \\
\hline $75-79$ & 310 & 45.5 & & \\
\hline $80-84$ & 208 & 30.5 & & \\
\hline$\geq 85$ & 163 & 23.9 & & \\
\hline Unknown & 0 & 0.0 & & \\
\hline \multicolumn{5}{|l|}{ T stage } \\
\hline T0 & 8 & 1.2 & & \\
\hline $\mathrm{T} 1$ & 214 & 31.4 & & \\
\hline $\mathrm{T} 2$ & 186 & 27.3 & & \\
\hline T3 & 19 & 2.8 & & \\
\hline T4 & 108 & 15.9 & & \\
\hline Unknown & 146 & 21.4 & & \\
\hline \multicolumn{5}{|l|}{$\mathrm{N}$ stage } \\
\hline No & 451 & 66.2 & & \\
\hline N1 & 112 & 16.4 & & \\
\hline N2 & 10 & 1.5 & & \\
\hline N3 & 2 & 0.3 & & \\
\hline Unknown & 106 & 15.6 & & \\
\hline \multicolumn{5}{|l|}{ M stage } \\
\hline MO & 579 & 85.0 & & \\
\hline M1 & 64 & 9.4 & & \\
\hline Unknown & 38 & 5.6 & & \\
\hline \multicolumn{5}{|l|}{ pT stage } \\
\hline $\mathrm{p} T 1$ & 259 & 38.0 & & \\
\hline p T2 & 206 & 30.2 & & \\
\hline p T3 & 20 & 2.9 & & \\
\hline p T4 & 64 & 9.4 & & \\
\hline$p T^{*}$ & 130 & 19.1 & & \\
\hline Unknown & 2 & 0.3 & & \\
\hline \multicolumn{5}{|l|}{ pN stage } \\
\hline p NO & 288 & 42.3 & & \\
\hline $\mathrm{p} \mathrm{N1}$ & 227 & 33.3 & & \\
\hline $\mathrm{pN}^{*}$ & 129 & 18.9 & & \\
\hline Unknown & 37 & 5.4 & & \\
\hline \multicolumn{5}{|l|}{ pM stage } \\
\hline $\mathrm{p} M 0$ & 576 & 84.6 & & \\
\hline p M1 & 64 & 9.4 & & \\
\hline Unknown & 41 & 6.0 & & \\
\hline
\end{tabular}

Table 1 Characteristics of patients $(\mathrm{N}=681)$ and tumours

(Continued)

pT staget

$\begin{array}{ccc}\text { рTO } & 1 & 0.1 \\ \text { pT1 }\end{array}$

$\begin{array}{lll}\mathrm{p} \mathrm{T1} & 282 & 41.4\end{array}$

$\begin{array}{lll}\mathrm{PT} 2 & 245 & 36.0\end{array}$

$\begin{array}{lll}\text { P T3 } & 26 & 3.8\end{array}$

$\begin{array}{lll}\text { p T4 } & 104 & 15.3\end{array}$

$\begin{array}{lll}\text { Unknown } & 23 & 3.4\end{array}$

pN staget

$\begin{array}{lll}\text { p NO } & 350 & 51.4\end{array}$

$\mathrm{p} \mathrm{N+} \quad 269 \quad 39.5$

Unknown $\quad 62 \quad 9.1$

pM staget

P MO $\quad 576 \quad 84.6$

$\begin{array}{lll}\text { p M1 } & 64 & 9.4\end{array}$

$\begin{array}{lll}\text { Unknown } & 41 & 6.0\end{array}$

Nodes removed

$\begin{array}{lll}\text { Nodes } \leq 10 & 389 & 57.1\end{array}$

$\begin{array}{lll}\text { Nodes }>10 & 223 & 32.7\end{array}$

$\begin{array}{lll}\text { Unknown } & 69 & 10.1\end{array}$

Positive nodes

$0 \quad 290 \quad 42.6$

$\begin{array}{lll}1-3 & 136 \quad 20.0\end{array}$

$\begin{array}{lll}\geq 4 & 93 & 13.7\end{array}$

$\begin{array}{lll}\text { Unknown } & 162 \quad 23.8\end{array}$

Histoprognostic SBR grade

$\begin{array}{lll}1 & 132 & 19.4\end{array}$

$2 \quad 350 \quad 51.4$

$3 \quad 160 \quad 23.5$

$\begin{array}{lll}\text { Unknown } & 39 & 5.7\end{array}$

Diagnosis circumstances

Clinic $\quad 471 \quad 69.2$

Individual screening $\quad 109 \quad 16.0$

$\begin{array}{lll}\text { Unknown } & 101 & 14.8\end{array}$

Place of residence

$\begin{array}{lll}\text { Urban } & 474 \quad 69.6\end{array}$

Rural $\quad 203 \quad 29.8$

Unknown $\quad 4 \quad 0.6$

Hormone receptors

Positive $\quad 590 \quad 86.6$

$\begin{array}{lll}\text { Negative } & 80 & 11.7\end{array}$

$\begin{array}{lll}\text { Unknown } & 11 & 1.6\end{array}$

Comorbidities

\begin{tabular}{lcc} 
Yes & 419 & 61.5 \\
No & 163 & 23.9 \\
Unknown & 99 & 14.5 \\
\hline
\end{tabular}




\begin{tabular}{|c|c|c|}
\hline \multicolumn{3}{|l|}{ Period } \\
\hline $1998-2003$ & 321 & 47.1 \\
\hline 2004-2008 & 360 & 52.9 \\
\hline Unknown & 0 & 0.0 \\
\hline \multicolumn{3}{|c|}{ Matrimonial status } \\
\hline Not single & 183 & 26.9 \\
\hline Singlef & 288 & 42.3 \\
\hline Unknown & 210 & 30.8 \\
\hline \multicolumn{3}{|c|}{ Having a family doctor } \\
\hline Yes & 621 & 91.2 \\
\hline No & 51 & 7.5 \\
\hline Unknown & 9 & 1.3 \\
\hline \multicolumn{3}{|l|}{ Vital status } \\
\hline Dead & 305 & 44.8 \\
\hline Alive & 376 & 55.2 \\
\hline Unknown & 0 & 0.0 \\
\hline
\end{tabular}

Abbreviations: $\mathrm{N}=$ number of patients; $\%$ = percentage; $\mathrm{SD}=$ standard deviations. "Patients without surgery;

†For patients without surgery pTNM stage was replaced by TNM; 'Patient single, divorced or widowed.

and period-matched mortality rates. The EMR was estimated in a generalized linear model with a Poisson error structure [23]. Follow-up time was stratified in annual intervals. Prognostic factors of survival were assessed using univariate and multivariate analyses of RS.

Univariate and multivariate logistic regression models were performed to identify the predictive factors of the administration of the different type of exclusive treatments: surgery alone, hormone therapy alone, BCS plus adjuvant therapy alone and mastectomy plus adjuvant therapy alone. Odds Ratios (OR) and their 95\% confidence intervals $(\mathrm{CI})$ are given.

For RS and logistic regression, all variables with a univariate $p$-value $\leq 0.20$ were eligible for multivariate analyses. Correlations and interactions were tested for eligible variables. To prevent co-linearity, when two variables were significantly correlated, one variable was retained according to its clinical relevance or to the value of the likelihood ratio. All reported $\mathrm{p}$ values are two sided. The statistical significance level was set at $\mathrm{p}<0.05$. Analyses were done using SAS (Statistical Analysis system version 9.2) and or STATA (version 9.0).

\section{Ethics statement}

The Breast and Gynaecologic Cancer Registry of Cote d'Or was approved by the CNIL (National Commission on Informatics and Liberties) for the collection and recording data for research purposes (authorization number DR-2012-038).

\section{Results}

Patients' characteristics

Seven hundred and fifteen (715) women aged 75 years and older with invasive primary $\mathrm{BC}$ were registered from January 1998 to December 2008. Among them, 34 were lost to follow-up at the date of diagnosis. Finally, 681 patients were included in the study. The median age at diagnosis was 80 (range, 75 to 98 years). The clinical and pathological features of the studied population are summarized in Table 1.

Information on comorbidities was missing for $14.5 \%$ of the women. The comorbidities recorded were: high blood pressure $(27 \%)$, diabetes $(5.4 \%)$, neurological disease $(3 \%)$, obesity $(1.2 \%)$, psychiatric illness (1\%), tuberculosis $(1.5 \%)$, thyroid disorder (4\%), previous history of stroke, heart failure or thrombosis $(8 \%)$, and previous history of disease affecting treatment administration (10\%).

\section{Treatment description}

Concerning treatment, 52 (7.6\%) underwent surgery alone, and hormone therapy alone was given to 74 (10.9\%). BCS plus adjuvant therapy was given to 238 (34.9) while 211 patients (31\%) received mastectomy plus adjuvant therapy. Nineteen $(2.8 \%)$ did not receive treatment and 26 patients (3.8\%) were treated by other treatments: chemotherapy alone or radiotherapy alone or chemotherapy plus hormone therapy or chemotherapy plus radiotherapy or radiotherapy plus hormone therapy or chemotherapy plus radiotherapy plus hormone therapy or neoadjuvant chemotherapy plus surgery plus adjuvant therapy or neoadjuvant chemotherapy plus surgery. For 1998-2003 and 2004-2008, the use of BCS plus adjuvant therapy ( $\mathrm{p}=0.63)$, mastectomy plus adjuvant therapy $(\mathrm{p}=0.52)$ and other treatments $(\mathrm{p}=0.43)$ was similar. In contrast, patients were less often treated by surgery alone in the second period ( $\mathrm{p}<0.001$ ): $11.2 \%$ and $4.4 \%$ for 1998-2003 and 2004-2008, respectively. The use of hormone therapy alone was more frequent in the second period ( $\mathrm{p}=0.001$ ): $6.5 \%$ and $14.7 \%$, respectively (Table 2 ).

Older patients were more likely to be treated with surgery alone $(\mathrm{p}=0.02)$ and with hormone therapy alone $(\mathrm{p}<0.001)$ and were more likely to receive no treatment $(\mathrm{p}=0.006)$. BCS plus adjuvant therapy $(\mathrm{p}<0.001)$ and other treatments $(p=0.03)$ were less likely to be given to older patients. In contrast, the use of mastectomy plus adjuvant therapy did not vary with age $(\mathrm{p}=0.40)$ (Table 3$)$.

\section{Prognostic factors and analyses of RS}

The median follow-up was 3 years $($ min-max $)=(0.01$ 11.96). At the cut-off, 305 deaths (45\%) had occurred. RS rates decreased with follow-up. RS at 1 year for the whole population was 93.5\%, 95\% CI $=$ [90.5-95.5] and at 5 years was $78.2 \%, 95 \% \mathrm{CI}=[72.2-83.0]$.

In the multivariate analysis, the pathological tumor size correlated with the $\mathrm{pT}$ stage, and we therefore retained the $\mathrm{pT}$ stage for the analyses. Examined and 
Table 2 Treatment description by period

\begin{tabular}{|c|c|c|c|c|c|c|c|}
\hline \multirow{2}{*}{$\begin{array}{l}\text { Period } \\
\text { Treatments }\end{array}$} & \multicolumn{2}{|c|}{$1998-2003(\mathrm{~N}=321)$} & \multicolumn{2}{|c|}{ 2004-2008 (N=360) } & \multirow[t]{2}{*}{$p$ value* } & \multicolumn{2}{|c|}{ All cases $(\mathrm{N}=681)$} \\
\hline & 321 & $\%$ & 360 & $\%$ & & 681 & $\%$ \\
\hline No treatment & & & & & 0.65 & & \\
\hline Yes & 10 & 3.1 & 9 & 2.5 & & 19 & 2.8 \\
\hline No & 306 & 95.3 & 340 & 94.4 & & 646 & 94.9 \\
\hline Unknown & 5 & 1.6 & 11 & 3.1 & & 16 & 2.3 \\
\hline Surgery alone & & & & & $<0.001$ & & \\
\hline Yes & 36 & 11.2 & 16 & 4.4 & & 52 & 7.6 \\
\hline No & 254 & 79.1 & 328 & 91.1 & & 582 & 85.5 \\
\hline Unknown & 31 & 9.7 & 16 & 4.4 & & 47 & 6.9 \\
\hline Hormone therapy & & & & & 0.001 & & \\
\hline Yes & 21 & 6.5 & 53 & 14.7 & & 74 & 10.9 \\
\hline No & 264 & 82.2 & 282 & 78.3 & & 546 & 80.2 \\
\hline Unknown & 36 & 11.2 & 25 & 6.9 & & 61 & 9.0 \\
\hline Breast conserving surgery plus adjuve & & & & & 0.63 & & \\
\hline Yes & 113 & 35.2 & 125 & 34.7 & & 238 & 34.9 \\
\hline No & 193 & 60.1 & 231 & 64.2 & & 424 & 62.3 \\
\hline Unknown & 15 & 4.7 & 4 & 1.1 & & 19 & 2.8 \\
\hline Mastectomy plus adjuvant therapy & & & & & 0.52 & & \\
\hline Yes & 95 & 29.6 & 116 & 32.2 & & 211 & 31.0 \\
\hline No & 210 & 65.4 & 230 & 63.9 & & 440 & 64.6 \\
\hline Unknown & 16 & 5.0 & 14 & 3.9 & & 30 & 4.4 \\
\hline Otherst & & & & & 0.43 & & \\
\hline Yes & 10 & 3.1 & 16 & 4.4 & & 26 & 3.8 \\
\hline No & 275 & 85.7 & 319 & 88.6 & & 594 & 87.2 \\
\hline Unknown & 36 & 11.2 & 25 & 6.9 & & 61 & 9.0 \\
\hline
\end{tabular}

Abbreviations: $\mathrm{N}=$ number of patients.

*Chi 2 test.

tOthers: chemotherapy alone, radiotherapy alone, chemotherapy plus hormone therapy, chemotherapy plus radiotherapy, radiotherapy plus hormone therapy, chemotherapy plus radiotherapy plus hormone therapy, neoadjuvant chemotherapy plus surgery plus adjuvant therapy, neoadjuvant chemotherapy plus surgery.

positive nodes correlated with clinical $\mathrm{N}$ stage and $\mathrm{pN}$ stage, respectively, and we retained the clinical $\mathrm{N}$ stage and $\mathrm{pN}$ stage for the analyses.

Multivariate RS analyses revealed an increased risk of death in patients with an advanced pT stage: Relative Excess Rates $($ RER $)=2.58,95 \% \mathrm{CI}=[1.23-5.42]$, in patients with metastasis at the time of diagnosis: $\mathrm{RER}=6.86,95 \%$ $\mathrm{CI}=[3.43-13.73]$ and in patients with comorbidities: $\mathrm{RER}=2.35,95 \% \mathrm{CI}=$ [1.03-5.36]. In contrast, a decreased risk of death was observed in patients who had a family doctor: $\mathrm{RER}=0.22,95 \% \mathrm{CI}=[0.07-0.68]$ and in patients with hormone-receptor positive tumours: RER $=0.33$, 95\% CI $=[0.16-0.70]$ (Table 4).

\section{Predictive factors of treatments administered}

Predictors of the treatments are listed in Table 5 . Patients with hormone-receptor positive tumours or patients diagnosed in the period from 2004 to 2008 were less likely to undergo surgery alone. OR were $0.29,95 \%$
$\mathrm{CI}=[0.12-0.72]$, and $0.40,95 \% \mathrm{CI}=[0.20-0.78]$, respectively. Older patients with metastasis did not receive surgery alone. The oldest patients ( $\geq 85$ years), patients with metastasis or with comorbidities were more often treated with hormone therapy alone. The oldest patients (80-84 and $\geq 85$ years) or patients with advanced tumours (stages $\mathrm{T} 2$ and $\mathrm{T} 3+\mathrm{T} 4$ ) were less likely to receive BCS plus adjuvant therapy. In contrast, patients with advanced tumours (stages $\mathrm{T} 2$ and $\mathrm{T} 3+\mathrm{T} 4$ ) were more likely to be treated with mastectomy plus adjuvant therapy, OR were $5.57,95 \% \mathrm{CI}=[3.09-10.03]$ and 3.60 , $95 \% \mathrm{CI}=[1.78-7.29]$, respectively. Patients with histoprognostic SBR grade 3 were more likely to be treated with mastectomy plus adjuvant therapy, $\mathrm{OR}=2.18,95 \%$ $\mathrm{CI}=[1.26-3.76]$. Moreover, there were interactions between age and the circumstances of diagnosis for the predictors of mastectomy plus adjuvant therapy $(\mathrm{p}<0.001)$. Indeed, patients aged $\geq 85$ years with a clinical diagnosis were $74 \%$ less likely to be treated with 
Table 3 Treatment description by age

\begin{tabular}{|c|c|c|c|c|c|c|c|c|c|}
\hline \multirow{2}{*}{$\frac{\text { Age }}{\text { Treatments }}$} & \multicolumn{2}{|c|}{$75-79(\mathrm{~N}=310)$} & \multicolumn{2}{|c|}{$80-84(\mathrm{~N}=208)$} & \multicolumn{2}{|c|}{$\geq 85(\mathrm{~N}=163)$} & \multirow[t]{2}{*}{$p$ value* } & \multicolumn{2}{|c|}{ All cases $(\mathrm{N}=681)$} \\
\hline & 310 & $\%$ & 208 & $\%$ & 163 & $\%$ & & 681 & $\%$ \\
\hline No treatment & & & & & & & 0.006 & & \\
\hline Yes & 4 & 1.3 & 6 & 2.9 & 9 & 5.5 & & 19 & 2.8 \\
\hline No & 304 & 98.1 & 197 & 94.7 & 145 & 89.0 & & 646 & 94.9 \\
\hline Unknown & 2 & 0.6 & 5 & 2.4 & 9 & 5.5 & & 16 & 2.3 \\
\hline Surgery alone & & & & & & & 0.02 & & \\
\hline Yes & 19 & 6.1 & 13 & 6.3 & 20 & 12.3 & & 52 & 7.6 \\
\hline No & 272 & 87.7 & 184 & 88.5 & 126 & 77.3 & & 582 & 85.5 \\
\hline Unknown & 19 & 6.1 & 11 & 5.3 & 17 & 10.4 & & 634 & 93.1 \\
\hline Hormone therapy & & & & & & & $<0.001$ & & \\
\hline Yes & 12 & 3.9 & 18 & 8.7 & 44 & 27.0 & & 74 & 10.9 \\
\hline No & 277 & 89.4 & 176 & 84.6 & 93 & 57.1 & & 546 & 80.2 \\
\hline Unknown & 21 & 6.8 & 14 & 6.7 & 26 & 16.0 & & 61 & 9.0 \\
\hline Breast conserving surgery plusadjuve & apy & & & & & & $<0.001$ & & \\
\hline Yes & 144 & 46.5 & 69 & 33.2 & 25 & 15.3 & & 238 & 34.9 \\
\hline No & 157 & 50.6 & 135 & 64.9 & 132 & 81.0 & & 424 & 62.3 \\
\hline Unknown & 9 & 2.9 & 4 & 1.9 & 6 & 3.7 & & 19 & 2.8 \\
\hline Mastectomy plus adjuvant therapy & & & & & & & 0.40 & & \\
\hline Yes & 92 & 29.7 & 83 & 39.9 & 36 & 22.1 & & 211 & 31.0 \\
\hline No & 208 & 67.1 & 116 & 55.8 & 116 & 71.2 & & 440 & 64.6 \\
\hline Unknown & 10 & 3.2 & 9 & 4.3 & 11 & 6.7 & & 30 & 4.4 \\
\hline Otherst & & & & & & & 0.03 & & \\
\hline Yes & 18 & 5.8 & 5 & 2.4 & 3 & 1.8 & & 26 & 3.8 \\
\hline No & 271 & 87.4 & 189 & 90.9 & 134 & 82.2 & & 594 & 87.2 \\
\hline Unknown & 21 & 6.8 & 14 & 6.7 & 26 & 16.0 & & 61 & 9.0 \\
\hline
\end{tabular}

Abbreviations: $\mathrm{N}=$ number of patients.

*Cochran-Armitage trend test.

tOthers: chemotherapy alone, radiotherapy alone, chemotherapy plus hormone therapy, chemotherapy plus radiotherapy, radiotherapy plus hormone therapy, chemotherapy plus radiotherapy plus hormone therapy, neoadjuvant chemotherapy plus surgery plus adjuvant therapy, neoadjuvant chemotherapy plus surgery.

mastectomy plus adjuvant therapy than were those aged between 75 and 79 years old with a clinical diagnosis.

\section{Discussion}

The results of this study showed that tumours were discovered at an advanced stage in elderly patients. Nine per cent of patients had metastatic tumours and 9.4\% had inflammatory tumours or tumours with extension to the skin or to the chest wall.

According to the follow-up period, older patients were less likely to be treated with surgery alone and more likely to receive hormone therapy alone in the more recent period. These results are in line with a study conducted by Bastiaannet et al, which showed that patients aged $\geq 75$ years were less likely to undergo surgery and more likely to have hormone therapy [24]. One possible explanation could be that more recently surgery alone was not proposed to treat $\mathrm{BC}$ because with the improvement in breast cancer management other, more effective treatments like hormone therapy or treatment combinations have been preferred to surgery alone to treat older women with $\mathrm{BC}$. Other explanations could be that elderly women with $\mathrm{BC}$ are too frail and have more advanced tumours associated with the presence of comorbidities.

Regarding the assessment of RS, the analyses were done on comprehensive data. Moreover, in this populationbased study, the follow-up for vital status was complete for all included patients with no patients lost to follow-up at the cut-off date. Our multivariate analyses of RS showed that $\mathrm{pT}$ stage, metastasis, having a family doctor, hormone receptor status and comorbidities were independent predictors of the length of survival. pT stage, metastasis and hormone receptor status have already been shown to be prognostic factors of survival in $\mathrm{BC}$ patients [6]. Indeed, the influence of hormone receptors could be attributed to the efficacy of hormone therapy given to patients with 
Table 4 Prognostic factors for relative survival

\begin{tabular}{|c|c|c|c|c|c|c|c|c|}
\hline \multirow[t]{2}{*}{ Factors } & \multirow[t]{2}{*}{$\mathrm{N}=(681)$} & \multirow[t]{2}{*}{ Number of deaths } & \multicolumn{3}{|c|}{ Univariate analysis } & \multicolumn{3}{|c|}{ Multivariate analysis $(\mathrm{N}=495)$} \\
\hline & & & RER & $95 \% \mathrm{Cl}$ & $p$ value & RER & $95 \% \mathrm{Cl}$ & $p$ value \\
\hline Age & 681 & & & & 0.001 & & & 0.18 \\
\hline $75-79$ & 310 & 107 & 1 & & & 1 & & \\
\hline $80-84$ & 208 & 88 & 0.99 & $0.52-1.88$ & & 1.01 & $0.47-2.16$ & \\
\hline$\geq 85$ & 163 & 110 & 2.75 & $1.68-4.48$ & & 2.15 & $1.02-4.55$ & \\
\hline pT stage & 658 & & & & $<0.001$ & & & 0.04 \\
\hline pT0+pT1 & 283 & 91 & 0.53 & $0.24-1.17$ & & 1.77 & $0.72-4.36$ & \\
\hline pT2 & 245 & 109 & 1 & & & 1 & & \\
\hline Pt3+Pt4 & 130 & 89 & 3.89 & $2.20-6.82$ & & 2.58 & $1.23-5.42$ & \\
\hline pN stage & 619 & & & & $<0.001$ & & & 0.14 \\
\hline pNO & 350 & 132 & 1 & & & 1 & & \\
\hline $\mathrm{pN}+$ & 269 & 135 & 3.13 & $1.68-5.75$ & & 1.75 & $0.80-3.83$ & \\
\hline pM stage & 640 & & & & $<0.001$ & & & $<0.001$ \\
\hline $\mathrm{pMO}$ & 576 & 227 & 1 & & & 1 & & \\
\hline $\mathrm{pM} 1$ & 64 & 47 & 10.18 & $6.11-16.95$ & & 6.86 & $3.43-13.73$ & \\
\hline Having a family doctor & 672 & & & & $<0.001$ & & & 0.03 \\
\hline No & 51 & 41 & 1 & & & 1 & & \\
\hline Yes & 621 & 258 & 0.17 & $0.11-0.28$ & & 0.22 & $0.07-0.68$ & \\
\hline Histoprognostic SBR grade & 642 & & & & $<0.001$ & & & 0.08 \\
\hline $1+2$ & 482 & 185 & 1 & & & 1 & & \\
\hline 3 & 160 & 93 & 2.73 & $1.66-4.51$ & & 1.87 & $0.93-3.79$ & \\
\hline Hormone receptors & 670 & & & & $<0.001$ & & & 0.006 \\
\hline Negative & 80 & 46 & 1 & & & 1 & & \\
\hline Positive & 590 & 255 & 0.38 & $0.23-0.63$ & & 0.33 & $0.16-0.70$ & \\
\hline Comorbidities & 582 & & & & 0.03 & & & 0.02 \\
\hline No & 163 & 51 & 1 & & & 1 & & \\
\hline Yes & 419 & 179 & 4.26 & $1.13-16.28$ & & 2.35 & $1.03-5.36$ & \\
\hline Diagnosis circumstances & 580 & & & & 0.10 & & & 0.13 \\
\hline Clinic & 471 & 209 & 1 & & & 1 & & \\
\hline Individual screening & 109 & 27 & 0.13 & $0.01-1.48$ & & 0.42 & $0.11-1.65$ & \\
\hline Place of residence & 677 & & & & 0.43 & & & \\
\hline Rural & 203 & 92 & 1 & & & & & \\
\hline Urban & 474 & 211 & 0.82 & $0.50-1.35$ & & & & \\
\hline Period & 681 & & & & 0.79 & & & \\
\hline $1998-2003$ & 321 & 190 & 1 & & & & & \\
\hline 2004-2008 & 360 & 115 & 1.07 & $0.66-1.73$ & & & & \\
\hline Matrimonial status & 471 & & & & 0.89 & & & \\
\hline Single* & 288 & 131 & 1 & & & & & \\
\hline Not single & 183 & 73 & 0.96 & $0.53-1.75$ & & & & \\
\hline
\end{tabular}

Abbreviations: $\mathrm{RER}=$ relative excess rates; $\mathrm{Cl}=$ confidence interval, $\mathrm{N}=$ number of patients.

${ }^{*}$ Patient single, divorced or widowed.

hormone-receptor positive tumours. A recent study showed that comorbidities had a significant impact on survival after $\mathrm{BC}$ with poorer survival among old patients with one or more comorbid conditions [25]. Patients who had a family doctor had a lower risk of death than those without a family doctor. This could be explained by the fact that patients who had a family doctor were more likely to be diagnosed with less advanced BC. 
Table 5 Multivariate logistic regression analysis of predictive factors of treatments administered

\begin{tabular}{llll}
\hline Variables & OR & $95 \% \mathrm{Cl}$ & $\mathrm{p}$ value \\
\hline
\end{tabular}

Predictive factors for surgery alone * $(\mathrm{N}=537)$

Age

75-79

80-84

$\geq 85$

$\mathrm{N}$ stage

NO

$\mathrm{N}+$

Hormone receptors

Negative

Positive

Period

1998-2003

2004-2008

Histoprognostic SBR grade

$1+2$

3

Place of residence

Rural

Urban

Predictive factors for hormone therapy alone $(\mathrm{N}=452)$

Age

75-79

80-84

$\geq 85$

T stage

$\mathrm{T} 0+\mathrm{T} 1$

$\mathrm{T} 2$

$\mathrm{T} 3+\mathrm{T} 4$

$\mathrm{N}$ stage

NO

$\mathrm{N}+$

$M$ stage

MO

M1

Comorbidities

No

Yes

Histoprognostic SBR grade

$1+2$

3

Period

\subsection{6}

$0.57-2.88$

$2.52 \quad 1.15-5.54$

0.05

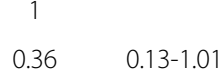

$0.29 \quad 0.12-0.72$

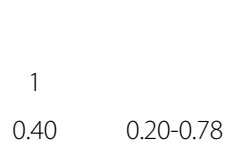

0.008

$0.40 \quad 0.20-0.78$

1.59

$0.72-3.49$

0.16

0.25

.25

$$
1
$$

1.84

0.78-4.33

$<0.001$

1

$\begin{array}{cc}2.07 & 0.80-5.35 \\ 16.22 & 6.74-39.03\end{array}$

16.22

$6.74-39.03$

$\begin{array}{cc}1 & \\ 1.21 & 0.53-2.74 \\ 1.22 & 0.42-3.52\end{array}$

0.89

0.52

$.32 \quad 0.57-3.07$

0.02

$3.67 \quad 1.25-10.74$

$<0.001$

1

$7.59 \quad 2.45-23.56$

0.22

1

0.55

$0.21-1.43$
Table 5 Multivariate logistic regression analysis of predictive factors of treatments administered (Continued)

\section{8-2003}

2004-2008

1.56

$0.75-3.24$

Hormone receptors

Negative

Positive

$4.73 \quad 0.90-24.94$

Diagnosis circumstances

Clinic

Individual screening

$0.72 \quad 0.24-2.13$

Place of residence

Rural

Urban

$0.47-2.12$

Predictive factors for BCS plus adjuvant therapy $+(\mathrm{N}=381)$

Age

$<0.001$

75-79

80-84

$0.53 \quad 0.30-0.95$

$\geq 85$

$0.21 \quad 0.09-0.50$

T stage

$<0.001$

$\mathrm{T} 0+\mathrm{T} 1$

$\mathrm{T} 2$

$0.17 \quad 0.09-0.31$

$\mathrm{T} 3+\mathrm{T} 4$

$0.13 \quad 0.05-0.30$

$\mathrm{N}$ stage

0.23

NO

$\mathrm{N}+$

$0.64 \quad 0.31-1.33$

Comorbidities

No

Yes

0.62

$0.34-1.12$

Diagnosis circumstances

Clinic

Individual screening

$1.71 \quad 0.90-3.24$

Histoprognostic SBR grade

$1+2$

3

Matrimonial status

Singleł

Not single

26

$0.73-2.17$

Hormone receptors

0.78

Negative

Positive

$1.14 \quad 0.46-2.83$

Predictive factors for mastectomy plus adjuvant therapy $(\mathrm{N}=381)$

T stage

$\mathrm{T} 0+\mathrm{T} 1$

T2

$\mathrm{T} 3+\mathrm{T} 4$

$5.57 \quad 3.09-10.03$

$3.60 \quad 1.78-7.29$ 


\begin{tabular}{|c|c|c|c|}
\hline N stage & & & 0.61 \\
\hline NO & 1 & & \\
\hline $\mathrm{N}+$ & 0.86 & $0.49-1.53$ & \\
\hline M stage & & & 0.07 \\
\hline MO & 1 & & \\
\hline M1 & 0.47 & $0.21-1.08$ & \\
\hline Histoprognostic SBR grade & & & 0.005 \\
\hline $1+2$ & 1 & & \\
\hline 3 & 2.18 & $1.26-3.76$ & \\
\hline Matrimonial status & & & 0.19 \\
\hline Single $\neq$ & 1 & & \\
\hline Not single & 0.72 & $0.44-1.18$ & \\
\hline Place of residence & & & 0.22 \\
\hline Rural & 1 & & \\
\hline Urban & 0.73 & $0.44-1.20$ & \\
\hline Age $\times$ diagnosis circumstances $\S$ & & & $<0.001$ \\
\hline 75-79 x clinical diagnosis & 1 & & \\
\hline 80-84 x clinical diagnosis & 1.63 & $0.91-2.93$ & \\
\hline$\geq 85 \times$ clinical diagnosis & 0.26 & $0.13-0.52$ & \\
\hline 75-79 $\times$ individual screening & 0.45 & $0.17-1.18$ & \\
\hline $80-84 \times$ individual screening & 0.33 & $0.09-1.18$ & \\
\hline$\geq 85 \times$ individual screening & 1.25 & $0.24-6.38$ & \\
\hline
\end{tabular}

Abbreviations: $\mathrm{OR}=$ Odds Ratios; $\mathrm{Cl}=$ confidence interval, $\mathrm{N}=$ number of patients.

*Predictive factors for surgery alone without the variable $M$ stage because no patient with stage $\mathrm{M} 1$ had surgery alone.

†Predictive factors for BCS plus adjuvant therapy without the variable M stage because only 4 patients with stage M1 received BCS plus adjuvant therapy. fpatient single, divorced or widowed.

§lnteraction age and diagnosis circumstances.

NB: Multivariate logistic regression analyses were adjusted for age, TNM stage, period, diagnosis circumstances, comorbidities, histoprognostic SBR grade, tumour type, hormone receptors, matrimonial status, and place of residence.

Five-year RS for our population was 78.2\%. The Eurocare-4 study, which analysed survival in cancer patients diagnosed from 1995 to 1999, showed that 5-year RS in France was $82.7 \%$ [26]. Survival was shorter in our population than in the whole population of BC patients in France. This could be due to the characteristics of our population, which was probably older than the population studied in Eurocare 4, and had comorbidities.

The results of this study showed that age was the major predictor of the type of treatment administered. The proportion of patients who had no treatment increased with age. Moreover, except for surgery and mastectomy plus adjuvant therapy, upon which age had no influence, the oldest patients were more often treated with hormone therapy and less likely to be treated with BCS plus adjuvant therapy, probably because of advanced stage of the tumour at discovery and the presence of comorbidities that preclude treatment with BCS in the elderly. These results are in line with those reported in other studies $[27,28]$. Adjuvant therapy (radiotherapy) after primary surgery was less frequent in the oldest age group with $\mathrm{BC}$. This was not the case for hormone therapy, which was more likely to be administered in the oldest patients than in patients in the youngest age group.

According to the characteristics of the tumour, older patients with an advanced tumour (stage T2, T3+T4) were more likely to undergo mastectomy plus adjuvant therapy and less likely to have BCS plus adjuvant therapy. This could be due to large tumour size which precludes BCS. Treatment with mastectomy plus adjuvant therapy limits organ invasion and thus decreases the risk of disease recurrence in the breast or distant metastasis. Another explanation could be the choice of the physician to avoid adjuvant radiotherapy for extremely frail women. Nevertheless, patients with hormone-receptor positive tumours were less often treated with surgery alone because these patients were usually treated with hormone therapy in accordance with the guidelines of the French health authorities [29]. Patients with metastasis were also more likely to receive hormone therapy, but less often treated with surgery. Surgery is a local treatment and is thus inadequate for the treatment of metastatic disease. Patients with comorbidities were more often treated with hormone therapy. Older patients with comorbidity received less aggressive treatments as shown in another study [28]. Treatments are often modified according to age-related issues such as comorbidity and the general state of health. This highlights the importance of considering comorbidities in the management of $\mathrm{BC}$.

The strength of this study is that the analyses were done in a heterogeneous and exhaustive group of patients, using data from the Cote d'Or breast and gynaecological cancer registry. Therefore, the results could be considered representative of elderly patients living in the department during this period. Cancer registries provide the unique opportunity to evaluate predictors of treatments given in routine practice and to assess survival using comprehensive population-based data. The use of RS makes it possible to correct for non-BC-related deaths while circumventing the problems associated with establishing the cause of death.

\section{Conclusions}

Comorbidity was associated with decreased survival in older women with breast cancer. Moreover, the results of this study showed that there are numerous predictors of the type of treatment administered, of which the most important were age and comorbidities.

\section{Abbreviations}

BC: Breast cancer; BCS: Breast conserving surgery; Cl: Confidence intervals; EMR: Excess mortality ratio; ES: Expected survival; RER: Relative excess rates; 
OR: Odds ratios; RS: Relative survival; SAS: Statistical analysis system; SBR: Scarff bloom and richardson; SD: Standard deviation.

\section{Competing interests}

The authors declare that they have no competing interests.

\section{Authors' contributions}

Authors' contributions were as follows: OD, TSD , SM, ,VQ, PA conceived the idea of the study, designed the study, collected data, performed statistical analyses, interpreted data, revised the manuscript and gave final approval to the version to be published. M-LP collected data, revised the manuscript and gave final approval to the version to be published. JG, PR, AD-J revised the manuscript and gave final approval to the version to be published. All authors read and approved the final manuscript.

\section{Acknowledgements}

We thank Ludovic Bouzigues for data collection and Philip Bastable, for correcting the manuscript. This work was supported by a grant from the "Ligue Nationale Contre le Cancer". The sponsor had no role in the design, methods, subject recruitment, data collections, analysis and preparation of this paper.

\section{Author details}

${ }^{1}$ Breast and Gynaecologic Cancer Registry of Cote d'Or, Centre Georges François Leclerc, 1 rue Professeur Marion BP 77980, Dijon Cedex 21079, France. ${ }^{2}$ EA 4184, Faculty of Medicine, University of Burgundy, 7 boulevard Jeanne d'Arc, Dijon 21000, France. ${ }^{3}$ Unité Pilote de Coordination en Oncogériatrie en Côte-d'Or, Hôpital de jour Gériatrique, Hôpital de Champmaillot, 2 rue Jules Violle, Dijon Cedex 21079, France. ${ }^{4}$ Centre de Pathologie, 33 rue Nicolas Bornier, Dijon 21000, France. ${ }^{5}$ Clinique Clément-Drevon, 9 rue Princes de Condé, Dijon 21000, France.

Received: 1 August 2012 Accepted: 9 October 2012 Published: 15 October 2012

\section{References}

1. Boyle P, Ferlay J: Cancer incidence and mortality in Europe 2004. Ann Oncol 2005, 16:481-488

2. Colonna M, Danzon A, De Lafosse P, Mitton N, Bara S, Bouvier A-M, Ganry O, Guizard A-V, Launoy G, Molinie F, Sauleau E-A, Schvartz C, Velten M, Grosclaude P, Tretarre B: Cancer prevalence in France: time trend, situation in 2002 and extrapolation to 2012. Eur J Cancer 2008, 44:115-122.

3. Belot A, Grosclaude P, Bossard N, Jougla E, Benhamou E, Delafosse $P$ Guizard AV, Molinié F, Danzon A, Bara S, Bouvier AM, Trétarre B, BinderFoucard F, Colonna M, Daubisse L, Hédelin G, Launoy G, Le Stang N, Maynadié M, Monnereau A, Troussard X, Faivre J, Collignon A, Janoray I, Arveux P, Buemi A, Raverdy N, Schvartz C, Bovet M, Chérié-Challine L, Estève $J$, Remontet $L$, Velten M: Cancer incidence and mortality in France over the period 1980-2005. Rev Epidemiol Sante Publique 2008, 56:159-175.

4. La situation du cancer en France en 2011: Collection rapports et synthèses, ouvrage collectif Edité par I'INCa. Boulogne-Billancourt:; 2011.

5. Kim KJ, Huh SJ, Yang JH, Park W, Nam SJ, Kim JH, Lee JH, Kang SS, Lee JE, Kang MK, Park YJ, Nam HR: Treatment results and prognostic factors of early breast cancer treated with a breast conserving operation and radiotherapy. Jpn J Clin Oncol 2005, 35:126-133.

6. Dabakuyo TS, Bonnetain F, Roignot P, Poillot M-L, Chaplain G, Altwegg T, Hedelin G, Arveux P: Population-based study of breast cancer survival in Cote d'Or (France): prognostic factors and relative survival. Ann Oncol 2008, 19:276-283.

7. Andrieu JM, Colonna P: Cancers: évaluation, traitement et surveillance. Paris: Ed ESTEM; 1997

8. DiGiovanna MP: Clinical significance of HER-2/neu overexpression: Part I. In Principles and practice of oncology. volume 13. 9th edition. Edited by DeVita VT Jr, Hellman S, Rosenberg SA. NJ: Lippincott Williams \& Wilkins Cedar Knolls; 1999.

9. Huiart L, Bardou V-J, Puig B, Maraninchi D: Improvement in breast cancer survival between 1975 and 2003 in a cohort of 5722 women. Bull Cancer 2006, 93:391-399.

10. Goldhirsch A, Ingle JN, Gelber RD, Coates AS, Thürlimann B, Senn H-J, Panel members: Thresholds for therapies: highlights of the St Gallen intenational expert consensus on the primary therapy of early breast cancer 2009. Ann Oncol 2009, 20:1319-1329.
11. Maraninchi $D$, Cerf $N$, Bousquet $P$, Lequellec-Nathan $M$, Danzon $A$, Belot $A$, Thuret A, Jougla E, Rey G, Grosclaude P, Colonna M, Bossard N, Canet C, Vongmany N: Dynamique d'évolution des taux de mortalité des principaux cancers en France. INCa; 2010:p42 http://www.e-cancer.fr/component/ docman/doc_download/5986-dynamique-devolution-des-taux-de-mortalitedes-principaux-cancers-en-france-novembre-2010.

12. Grosclaude P, Colonna M, Hedelin G, Tretarre B, Arveux P, Lesec'h JM, Raverdy N, Sauvage-Machelard M: Survival of women with breast cancer in France: variation with age, stage and treatment. Breast Cancer Res Treat 2001, 70:137-143.

13. Bouchardy C, Rapiti E, Fioretta G, Laissue P, Neyroud-Caspar I, Schäfer P, Kurtz J, Sappino A-P, Vlastos G: Undertreatment strongly decreases prognosis of breast cancer in elderly women. J Clin Oncol 2003, 21:3580-3587.

14. Van Leeuwen BL, Rosenkranz KM, Lei Feng L, Bedrosian I, Hartmann K, Hunt KK, Kuerer HM, Ross M, Singletary SE, Babiera GV, the Department of Surgical Oncology, MD Anderson Cancer Center: The effect of undertreatment of breast cancer in women 80 years of age and older. Crit Rev Oncol Hematol 2011, 79:315-320.

15. Hughes KS, Schnaper LA, Berry D, Cirrincione C, McCormick B, Shank B, Wheeler J, Champion LA, Smith TJ, Smith BL, Shapiro C, Muss HB, Winer E, Hudis C, Wood W, Sugarbaker D, Henderson IC, Norton L: Lumpectomy plus tamoxifen with or without irradiation in women 70 years of age or older with early breast cancer. N Engl J Med 2004, 351:971-977.

16. Early Breast Cancer Trialists' Collaborative Group (EBCTCG): Effects of chemotherapy and hormonal therapy for early breast cancer on recurrence and 15-year survival: an overview of the randomised trials. Lancet 2005, 365:1687-1717.

17. Mandelblaltt J, Kreling B, Figeuriedo M, Feng S: What is the impact of shared decision making on treatment and outcomes for older women with breast cancer? J Clin Oncol 2006, 24:4908-4913.

18. Bouchardy C, Rapiti E, Blagojevic S, Vlastos A-T, Vlastos G: Older female cancer patients: importance, causes, and consequences of undertreatment. J Clin Oncol 2007, 25:1858-1869.

19. Giordano SH, Hortobagyi GN, Kau S-WC, Theriault RL, Bondy ML: Breast cancer treatment guidelines in older women. J Clin Oncol 2005, 23:783-791.

20. Faivre J, Lemmes VEPP, Quipourt V, Bouvier AM: Management and survival of colorectal cancer in the elderly in population based-studies. Eur J Cancer 2007, 43:2279-2284.

21. Sobin LH, Wittekind C (Eds): International Union Against Cancer (UICC): TNM classification of malignant tumors. 5th edition. New York, NY: John Wiley \& Sons, Inc; 1997.

22. Ederer F, Axtell LM, Cutler SJ: The relative survival rate: a statistical methodology. Natl Cancer Inst Monogr 1961, 6:101-121.

23. Dickman PW, Sloggett A, Hills M, Hakulinen T: Regression models for relative survival. Stat Med 2004, 23:51-64

24. Bastiaannet E, Portielje JEA, Van de Velde CJH, Craen AJM, Van der Velde S, Kuppen PJK, Van der Geest LGM, Janssen-Heijnen MLG, Dekkers OM, Westendorp RGJ, Liefers G-J: Lack of survival gain for elderly women with breast cancer. Oncologist 2011, 16:415-423.

25. Land LH, Dalton SO, Jørgensen TL, Ewertz M: Comorbidity and survival after early breast cancer. A review. Crit Rev Oncol Hematol 2011, 81:196-205.

26. Berrino F, De Angelis R, Sant M, Rosso S, Lasota MB, Coebergh JW, Santaquilani M, EUROCARE working group: Survival for eight major cancers and all cancers combined for European adults diagnosed in 1995-99: results of the EUROCARE-4 study. Lancet Oncol 2007, 8:773-783.

27. Weggelaar I, Aben KK, Warlé MC, Strobbe LJ, Van Spronsen DJ: Declined guideline adherence in older breast cancer patients: a population-based study in The Netherlands. Breast J 2011, 17:239-245.

28. Schonberg MA, Marcantonio ER, Li D, Silliman RA, Ngo L, McCarthy EP: Breast cancer among the oldest old: tumor characteristics, treatment choices, and survival. J Clin Oncol 2010, 28:2038-2045.

29. NIH consensus statement: adjuvant therapy for breast cancer. http://consensus.nih.gov/2000/2000AdjuvantTherapyBreastCancer114PDF.pdf.

doi:10.1186/1471-2407-12-472

Cite this article as: Dialla et al:: Population-based study of breast cancer in older women: prognostic factors of relative survival and predictors of treatment. BMC Cancer 2012 12:472. 